\title{
Digit Ratio (Ratio of Second and Fourth Digit Lengths) in Turkish Male Patients with Myocardial Infarction
}

\section{Miyokard Enfarktüsü Geçiren Türk Erkek Hastalarda İkinci ve Dördüncü Parmak Oranının Değerlendirilmesi}

\author{
Fatma Nihan Turhan Çağlar, (1) Cennet Yıldız, (1) Ece Çelebi Coşkun \\ University of Health Sciences Turkey, Bakırköy Dr. Sadi Konuk Training and Research Hospital, Clinic of Cardiology, Istanbul, Turkey
}

\begin{abstract}
Objective: Digit ratio (ratio of second and fourth digit lengths or 2D:4D) is assumed to be negatively correlated with prenatal testosterone level. Prenatal hormonal exposure is associated with various diseases in adulthood; however, data regarding the relationship between 2D:4D ratios and myocardial infarction (MI) localization and demographic characteristics of male patients with a history of MI is limited. Thus, this study aimed to evaluate the association between $2 \mathrm{D}: 4 \mathrm{D}$ ratios and history of $\mathrm{MI}$ in male patients in respect to cardiovascular risk factors and $\mathrm{MI}$ localization.

Methods: The ratios of 2D:4D of both hands of 140 consecutive male patients with a history of Ml were measured and recorded. The right and left-hand 2D:4D ratios were compared among different age groups, cardiovascular risk factors, and Ml localization.

Results: The average age of participants was $57.56 \pm 11.27$ years, $13.6 \%(n=19)$ of cases were $30-45,32.1 \%(n=45)$ were $46-55,28.6 \%(n=40)$ were $56-65$, and $25.7 \%(n=36)$ were over 65 years old. Average digit ratio of the right and left hand were $0.98 \pm 0.05 \mathrm{~cm}$ and $0.96 \pm 0.04 \mathrm{~cm}$, respectively. The right versus left 2D:4D was not statistically different according to any age groups, cardiovascular risk factors, and MI localization ( $p>0.05)$.

Conclusion: No differences were found in 2D:4D digit ratios of both hands in Turkish male patients with MI history and were not associated with cardiovascular risk factors and MI localization.
\end{abstract}

Keywords: Myocardial infarction, digit ratio (2D:4D), testosterone

öz

Amaç: İkinci parmak ve 4. parmak (2D:4D) oranının doğum öncesi testesteron seviyesi ile negatif ilişki gösterdiği düşünülmektedir. Doğum öncesi hormon seviyelerinin yetişkinlikte pek çok hastalık ile birlikte olmasına rağmen, 2D:4D oranı ile miyokardiyal enfartüs (MI) lokalizasyonu ve $\mathrm{Ml}$ anamnezi olan erkek hastaların demografik özellikleri hakkındaki veriler sınırlıdır. Bu çalışmada MI anamnezi olan erkek hastalarda 2D:4D oranı ile kardiyovasküler risk faktörleri ile Mı lokalizasyonu arasındaki olası ilişkileri değerlendirmeyi amaçladık.

Gereç ve Yöntem: MI anamnezi olan ardışık 140 erkek hastanın 2D:4D oranı ölçüldü. Sağ ve sol el 2D:4D oranı kardiyovasküler risk faktörleri, MI lokalizasyonu ve yaş grupları açısından değerlendirildi.

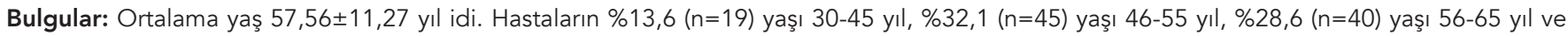

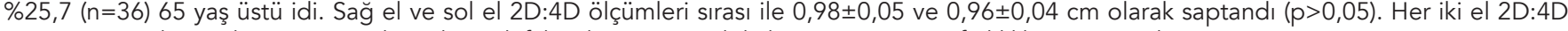
oranı yaş gruplarına, koroner arter hastalığı risk faktörlerine ve Mı lokalizasyonuna göre farklılık göstermedi.

Sonuç: MI geçirmiş olan Türk erkek hastalarda her sağ-sol el 2D:4D oranı, kardiyovasküler risk faktörleri ve Mı lokalizasyonu açısından fark gözlenmemiştir.

Anahtar Kelimeler: Miyokard enfartküsü, parmak oranı (2D:4D), testosteron

Address for Correspondence: Fatma Nihan Turhan Çağlar, University of Health Sciences Turkey, Bakırköy Dr. Sadi Konuk

Training and Research Hospital, Clinic of Cardiology, Istanbul, Turkey

Phone: +90 5326879101 E-mail: nhnturhan@gmail.com ORCID ID: orcid.org/0000-0001-7925-2398

Cite as: Turhan Çağlar FN, Yıldız C, Çelebi Coşkun E. Digit Ratio (Ratio of Second and Fourth Digit Lengths) in Turkish Male Patients with

Myocardial Infarction. Med J Bakirkoy 2021;17:407-411

Received:1.11.2021

Accepted: 30.11 .2021 


\section{INTRODUCTION}

The human ratio of the second finger (index finger) to the fourth finger (ring finger) length (2D:4D) is smaller in males compared to females (1). Previous studies revealed that fetal testosterone and estrogen exposure may affect this ratio $(1,2)$. Higher $2 \mathrm{D}: 4 \mathrm{D}$ is associated with increased intrauterine exposure to luteinizing hormone, prolactin, and estrogen levels, and decreased testosterone exposure (3-5). The fetal testosterone/estrogen ratio in the amniotic fluid was negatively correlated with the 2D:4D ratio. Moreover, patients with Klinefelter's syndrome had a higher 2D:4D ratio compared to their normal counterparts (1-3) The 2D:4D ratio in humans also varies between ethnic groups, for example, Afro-Caribbean Jamaicans had a lower ratio compared to Caucasian Uygurs (4). Its relationship with various physiological, behavioral, and pathological conditions, such as obesity and metabolic syndrome, has been demonstrated in various studies (5-9). Patients with female congenital adrenal hyperplasia had a higher 2D:4D ratio compared to controls (6).

Traditional coronary artery disease (CAD) risk factors are clearly-defined, whereas the effect of different risk factors, such as genetic predisposition and inflammatory markers, are still evaluated (10). Myocardial infarction (MI) prevalence is higher in males than females in the pre-menopausal period; however, the difference decreases at later ages (11). Additionally, low endogenous testosterone levels are related to $\mathrm{Ml}$ in males (12). Moreover, a high 2D:4D ratio might be a predisposing factor for MI history at an early age in males $(7,8,13)$. Ozdogmus et al. (9) conducted a study on the autopsy of 100 male patients and revealed that the righthand ratio was related to atherosclerotic plaque burden in the right coronary arteries.

A small number of studies evaluated the association between 2D:4D and CAD; however, the link between this ratio and age or Ml localization has not yet been reported in the literature. Thus, this study aimed to compare 2D:4D ratios according to age, other CAD risk factors, and $\mathrm{Ml}$ localization in Turkish male patients with MI history.

\section{METHODS}

This cross-sectional, single-center, and retrospective study included 140 male patients with previous Ml. All patients were from the Turkish ethnic group. Data regarding the demographic characteristics of patients were obtained from hospital registries. Age, presence of diabetes mellitus $(D M)$, hypertension $(H T)$, hyperlipidemia $(H L)$, history and quantity of smoking, $\mathrm{Ml}$ localization, and family history were recorded. Acute MI was defined by the criteria of the related guidelines (14). HT was defined as a systolic blood pressure of $\geq 140 \mathrm{mmHg}$ or a diastolic blood pressure of $\geq 90 \mathrm{mmHg}$ at presentation, previous diagnosis of $\mathrm{HT}$, or antihypertensive usage. DM was described as a fasting blood glucose level of $\geq 126 \mathrm{mg} / \mathrm{dL}$ or antidiabetic medication usage. The use of antilipemic agents or serum low-density lipoproteins-cholesterol concentration of $>70$ $\mathrm{mg} / \mathrm{dL}$ was described as HL. Patients with hand deformities, thyroid dysfunction, hormonal disorders, genetic diseases, using hormonal therapies, and left-hand users were excluded. Our Hospital Local Ethics Committee University of Health Sciences Istanbul, Turkey Bakırköy Dr. Sadi Konuk Training and Research Hospital approved the study and informed consent was obtained from all participants. The study was conducted in accordance with the principles of the Declaration of Helsinki (ethical approval number: 201812-04, date: 06. 25.2018).

\section{Measurement of Finger Lengths}

The index and ring finger lengths of both hands were measured using a ruler in the palmar surface, starting from the proximal palm's basal crease to the tip of the finger. An independent examiner blinded to the study measured the finger lengths and calculated the 2D:4D ratio.

\section{Statistical Analysis}

Data were statistically analyzed using the Number Cruncher Statistical System 2007 (Kaysville, Utah, USA). Data were expressed as mean, standard deviation, median, frequency, percentage, minimum, and maximum. Normal distribution conformity of quantitative data has been tested with the Shapiro-Wilk test and graphical examinations. Comparison of quantitative variables of two groups with normal distribution was made by the Student's t-test. One-Way analysis of variance and Kruskal-Wallis test was used for the comparison of parametric and non-parametric variables of more than two groups, respectively.

\section{RESULTS}

The group average age was $57.56 \pm 11.27$ years, wherein $13.6 \%$ $(n=19)$ of patients were aged $30-45,32.1 \%(n=45)$ were 46 $55,28.6 \%(n=40)$ were $56-65$ years, and $25.7 \%(n=36)$ were over 65 years. Inferior $\mathrm{Ml}$ was determined in $48.6 \%(n=68)$ of patients, anterior $\mathrm{MI}$ in $32.9 \%(\mathrm{n}=46)$, septal $\mathrm{MI}$ in $3.6 \%$ $(n=5)$, posterior $\mathrm{Ml}$ in $2.9 \%(n=4)$, and lateral $\mathrm{Ml}$ in $12.1 \%$ $(n=17)$. Table 1 shows the demographic characteristics of the study population. Finger length measurements of the total group are summarized in Table 2 . The average right- 
Turhan Çağlar et al. Digit Ratio (2D:4D) and Myocardial Infarction

Table 1. Demographic characteristics of patients

\begin{tabular}{|c|c|c|}
\hline & Total & $57.56 \pm 11.27$ \\
\hline \multirow{4}{*}{ Age n (\%) } & $30-45$ years & $19(13.6)$ \\
\hline & $46-55$ years & $45(32.1)$ \\
\hline & $56-65$ years & $40(28.6)$ \\
\hline & $>65$ years & $36(25.7)$ \\
\hline Diabetes, n (\%) & - & $35(25.0)$ \\
\hline Hypertension, n (\%) & - & $53(37.9)$ \\
\hline Smoking, n (\%) & - & $118(84.3)$ \\
\hline Family history, n (\%) & - & $31(22.1)$ \\
\hline Hyperlipidemia & - & $33(23.5)$ \\
\hline \multirow{5}{*}{ MI localization, n (\%) } & Inferior MI & $68(48.6)$ \\
\hline & Anterior MI & $46(32.9)$ \\
\hline & Septal MI & $5(3.6)$ \\
\hline & Posterior Ml & $4(2.9)$ \\
\hline & Lateral MI & $17(12.1)$ \\
\hline
\end{tabular}

Table 2. Finger length measurements of patients

\begin{tabular}{ll} 
& Mean \pm SD \\
\hline Right $2^{\text {nd }}$ finger $(\mathrm{mm})$ & $72.93 \pm 5.80$ \\
\hline${\text { Right } 4^{\text {th }}}$ finger $(\mathrm{mm})$ & $74.24 \pm 6.89$ \\
\hline Right $2^{\text {nd }} / 4^{\text {th }}$ finger & $0.98 \pm 0.05$ \\
\hline Left $2^{\text {nd }}$ finger $(\mathrm{mm})$ & $71.55 \pm 6.91$ \\
\hline${\text { Left } 4^{\text {th }}}^{\text {finger }}(\mathrm{mm})$ & $74.49 \pm 6.50$ \\
\hline Left $2^{\text {nd }} / 4^{\text {th }}$ finger & $0.96 \pm 0.04$ \\
\hline
\end{tabular}

SD: Standard deviation

hand finger ratio was $0.98 \pm 0.05 \mathrm{~cm}$ and left hand was $0.96 \pm 0.04 \mathrm{~cm}$. Table 3 demonstrates the comparison of leftright 2D:4D according to age subgroups, CAD risk factors, and $\mathrm{Ml}$ localization. The right versus left 2D:4D was not statistically different according to any age groups, CAD risk factors, or MI localization ( $p>0.05$ ).

\section{DISCUSSION}

This study revealed no statistically significant differences in the 2D:4D ratio of both hands according to age groups, presence of DM, HT, smoking, family history, or MI localization. To the best of our knowledge, the present study was the first one that evaluates the association between the 2D:4D ratio and $\mathrm{Ml}$ in different age groups, CAD risk factors, and $\mathrm{Ml}$ localization.
Table 3. Right and left-hand 2D:4D ratio according to age, cardiovascular risk factors, and MI localization

\begin{tabular}{|c|c|c|c|}
\hline \multirow[b]{2}{*}{ Mean \pm SD } & & Right & Left \\
\hline & & \multicolumn{2}{|l|}{ Mean \pm SD } \\
\hline \multirow{5}{*}{ Age } & $\begin{array}{l}30-45 \text { years } \\
(n=19)\end{array}$ & $0.99 \pm 0.04$ & $0.95 \pm 0.05$ \\
\hline & $\begin{array}{l}46-55 \text { years } \\
(n=45)\end{array}$ & $0.98 \pm 0.04$ & $0.96 \pm 0.05$ \\
\hline & $\begin{array}{l}56-65 \text { years } \\
(n=40)\end{array}$ & $0.97 \pm 0.06$ & $0.95 \pm 0.04$ \\
\hline & $\begin{array}{l}>65 \text { years } \\
(n=36)\end{array}$ & $0.98 \pm 0.05$ & $0.96 \pm 0.04$ \\
\hline & $p$ & ${ }^{\mathrm{a}} 0.580$ & a 0.432 \\
\hline \multirow{2}{*}{ Diabetes } & - & $0.98 \pm 0.05$ & $0.95 \pm 0.05$ \\
\hline & $p$ & ' 0.765 & b 0.573 \\
\hline \multirow{2}{*}{ Hypertension } & - & $0.97 \pm 0.05$ & $0.95 \pm 0.04$ \\
\hline & $p$ & b0.109 & b 0.754 \\
\hline \multirow[t]{2}{*}{ Hyperlipidemia } & - & $0.98 \pm 0.05$ & $0.95 \pm 0.05$ \\
\hline & $p$ & ' 0.741 & ' 0.774 \\
\hline \multirow{2}{*}{ Smoking } & - & $0.98 \pm 0.05$ & $0.96 \pm 0.04$ \\
\hline & $p$ & b 0.534 & b 0.483 \\
\hline \multirow{2}{*}{ Family History } & - & $0.98 \pm 0.05$ & $0.95 \pm 0.04$ \\
\hline & $p$ & b0.741 & b 0.773 \\
\hline \multirow{6}{*}{ MI localization } & Inferior $(n=68)$ & $0.98 \pm 0.05$ & $0.96 \pm 0.05$ \\
\hline & Anterior $(n=46)$ & $0.98 \pm 0.04$ & $0.96 \pm 0.04$ \\
\hline & Septal $(n=5)$ & $0.98 \pm 0.05$ & $0.96 \pm 0.02$ \\
\hline & Posterior $(n=4)$ & $0.95 \pm 0.03$ & $0.91 \pm 0.04$ \\
\hline & Lateral $(n=17)$ & $0.99 \pm 0.05$ & $0.96 \pm 0.03$ \\
\hline & $p$ & ${ }^{c} 0.686$ & ${ }^{c} 0.397$ \\
\hline
\end{tabular}

aOne-Way ANOVA, bStudent's t-test, 'Kruskal-Wallis test, MI: Myocardial infarction, SD: Standard deviation

Prenatal exposure to androgenic hormones has been shown to affect the digit ratio of humans. Malas et al. (15) revealed that female fetuses have higher 2D:4D digit ratios than males. A study conducted by Lutchmaya et al. (1) revealed that 2D:4D ratios of 2-year-old children were associated with high fetal testosterone levels in the amniotic fluid with estradiol. Additionally, the right hand was more sensitive to the effect of sex steroids than the left. Other studies also showed that testosterone exposure is more effective in the development of the right side of the body than the left side $(16,17)$. The $2 \mathrm{D}: 4 \mathrm{D}$ ratio of the right hand and waist-body circumference, which is a predictor for metabolic syndrome, was demonstrated to be statistically significantly higher than the left hand (5). Although statistically insignificant, the 
2D:4D ratio of the right hand was also higher than the left hand in our study.

The changes of the 2D:4D after birth are controversial. Studies on this topic have found conflicting findings. Some research found lower 2D:4D ratios in the prenatal period compared to childhood and adulthood, which indicates that the digit ratio increases after birth (18). A longitudinal study reported that an increased 2D:4D was less marked in the right hand, which is more likely to be affected by prenatal steroid levels (19). Contrarily, some data indicate relatively stable values of 2D:4D ratios during lifetime (20). Similarly, our study revealed that the right and left-hand $2 D: 4 D$ ratios were not different among the age groups.

Previous studies revealed that the $2 \mathrm{D}: 4 \mathrm{D}$ ratio was a predictor of $\operatorname{CAD}(7,8,21,22)$. Chinese females with $C A D$ had a lower 2D:4D ratio compared to control subjects (23). Viveka et al. (24) revealed a strong association between finger ratio and diagonal ear lobe crease, which is also considered as an indicator of atherosclerosis. Ozdogmus et al. (9) demonstrated that males who had atherosclerotic plaque in the right coronary arteries had a higher righthand 2D:4D ratio than males without plaques. Wu et al. (21) revealed a higher $2 D: 4 D$ ratio in males with $C A D$ than females with CAD, as well as a positive correlation between the $2 D: 4 D$ ratio and $C A D$ in males, but not in females. Additionally, the right-hand 2D:4D ratio had higher discriminative power for CAD. Another study showed that males with a high right-hand digit ratio had $\mathrm{Ml}$ at a younger age compared to subjects with a low digit ratio (13). The right side of the body is more androgen-sensitive during the prenatal period and the low right-hand digit ratio is correlated with high prenatal and adult testosterone levels. High testosterone levels are is known to be protective against $C A D$ and $M I$ in males. The right and left sides of the body react differently to androgenic stimulation, thus an association between Ml localization with the right and left-hand 2D:4D ratios was investigated. Our study revealed that MI localization was not different between the right and left-hand measurements. Similarly, the 2D:4D ratio has been linked to CAD risk factors, including HT, DM, and metabolic syndrome $(5,25)$. Our results revealed that the right and lefthand digit ratios were not different in our study group in their CAD risk factors.

\section{Study Limitations}

The present study was a single-center study with a relatively small sample size, which may limit the generalization of our results. Only the 2D:4D ratio in male patients with $\mathrm{MI}$ history was measured without a control group that included subjects without MI history. However, studies are reported in the literature, which compared the 2D:4D ratio in $\mathrm{Ml}$ versus healthy patients (19). Hence, our study aimed to evaluate the 2D:4D ratio in different age subgroups, $C A D$ risk factors, and $\mathrm{Ml}$ localization to add new findings to the current literature.

\section{CONCLUSIONS}

In male patients with $\mathrm{Ml}$ history, the $2 \mathrm{D}: 4 \mathrm{D}$ ratio is not associated with CAD risk factors and MI localization.

\section{ETHICS}

Ethics Committee Approval: Our Hospital Local Ethics Committee University of Health Sciences Turkey, Bakırköy Dr. Sadi Konuk Training and Research Hospital approved the study. The study was conducted in accordance with the principles of the Declaration of Helsinki (ethical approval number: 2018-12-04, date: 06. 25.2018).

Informed Consent: Informed consent was obtained from all participants.

\section{Authorship Contributions}

Surgical and Medical Practices: E.Ç.C., Concept: F.N.T.Ç., Design: F.N.T.Ç., E.Ç.C., Data Collection or Processing: E.Ç.C., Analysis or Interpretation: C.Y., Literature Search: C.Y., Writing: F.N.T.Ç.

Conflict of Interest: No conflict of interest was declared by the authors.

Financial Disclosure: The authors declared that this study received no financial support.

\section{REFERENCES}

1. Lutchmaya S, Baron-Cohen S, Raggatt P, Knickmeyer R, Manning JT. 2nd to 4th digit ratios, fetal testosterone and estradiol. Early Hum Dev 2004;77:23-8.

2. Knickmeyer RC, Woolson S, Hamer RM, Konneker T, Gilmore J. 2D:4D ratios in the first 2 years of life: stability and relation to testosterone exposure and sensitivity. Horm Behav 2011;60:256-63.

3. Manning JT, Kilduff LP, Trivers R. Digit ratio (2D: 4D) in Klinefelter's syndrome. Andrology 2013;1:94-9.

4. Manning JT, Stewart A, Bundred PE, Trivers RL. Sex and ethnic differences in 2 nd to 4 th digit ratio of children. Early Hum Dev 2004;80:161-8.

5. Oyeyemi BF, lyiola OA, Oyeyemi AW, Oricha KA, Anifowoshe AT, Alamukii NA. Sexual dimorphism in ratio of second and fourth digits and its relationship with metabolic syndrome indices and cardiovascular risk factors. J Res Med Sci 2014;19:234-9.

6. Okten A, Kalyoncu M, Yariş N. The ratio of second- and fourth-digit lengths and congenital adrenal hyperplasia due to 21 -hydroxylase deficiency. Early Hum Dev 2002;70:47-54.

7. Manning JT, Bundred PE, Kasielska-Trojanc A, Smith-Straneyd T, Mason L. Digit ratio (2D:4D), myocardial infarction and fibrinogen in men. Early Hum Dev 2019;133:18-22.

8. Fink B, Manning JT, Neave N. The 2nd-4th digit ratio (2D:4D) and neck circumference: implications for risk factors in coronary heart disease. Int J Obes (Lond) 2006;30:711-4. 
9. Ozdogmus O, Çakmak YO, Coskun M, Verimli U, Cavdar S, Uzun I. The high 2D:4D finger length ratio effects on atherosclerotic plaque development. Atherosclerosis 2010;209:195-6.

10. Caglar FNT, Biyik I, Isıksacan N, Hancer VS, Akturk IF, Ciftci S, et al. P-selectin glycoprotein ligand-1 variable number of tandem repeats polymorphism in young myocardial infarction patients. Arc Med Sci Civil Dis 2016;1:112-6.

11. Uemura K, Pisa Z. Trends in cardiovascular disease mortality in industrialized countries since 1950. World Health Stat Q 1988;41:155-78.

12. Malkin CJ, Pugh PJ, Morris PD, Asif S, Jones TH, Channer KS. Low serum testosterone and increased mortality in men with coronary heart disease. Heart 2010;96:1821-5.

13. Manning JT, Bundred PE. The ratio of 2 nd to 4 th digit length and age at first myocardial infarction in men: a link with testosterone? Br J Cardiol 2001;8:720-3.

14. Thygesen K, Alpert JS, Jaffe AS, Chaitman BR, Bax JJ, Morrow DA, et al. Fourth Universal Definition of Myocardial Infarction (2018). Glob Heart 2018;13:305-38.

15. Malas MA, Dogan S, Evcil EH, Desdicioglu K. Fetal development of the hand, digits and digit ratio (2D:4D). Early Hum Dev 2006;82:46975.

16. Kraemer B, Noll T, Delsignore A, Milos G, Schnyder U, Hepp U. Finger length ratio (2D:4D) and dimensions of sexual orientation. Neuropsychobiology 2006;53:210-4.

17. Hönekopp J, Watson S. Meta-analysis of digit ratio 2D:4D shows greater sex difference in the right hand. Am J Hum Biol 2010;22:61930 .
18. Galis F, Ten Broek CM, Van Dongen S, Wijnaendts LC. Sexual dimorphism in the prenatal digit ratio (2D:4D). Arch Sex Behav 2010;39:57-62.

19. Trivers R, Manning J, Jacobson A. A longitudinal study of digit ratio (2D:4D) and other finger ratios in Jamaican children. Horm Behav 2006:49:150-6.

20. Manning JT, Scutt D, J, Lewis-Jones DI. The ratio of 2 nd to 4 th digit length: a predictor of sperm numbers and concentrations of testosterone, luteinizing hormone and oestrogen. Hum Reprod 1998;13:3000-4.

21. $W u X L$, Yang $D Y$, Chai $W H$, Jin $M L$, Zhou $X C$, Peng $L$, et al. The ratio of second to fourth digit length (2D:4D) and coronary artery disease in a Han Chinese population. Int J Med Sci 2013;10:1584-8.

22. Kyriakidis I, Papaioannidou P, Pantelidou V, Kalles V, Gemitzis K. Digit ratios and relation to myocardial infarction in Greek men and women. Gend Med 2010;7:628-36.

23. Wang L, Huo Z, Lu H, Bai C, Li C, Ma. Digit ratio (2D:4D) and coronary artery disease in north Chinese women. Early Hum Dev 2018;116:64-7.

24. Viveka S, Sagar TV, Kumar JA. Evaluation of 2D:4D digit ratio and diagonal earlobe crease as markersof coronary artery disease. Journal of the Anatomical Society of India 2016;65:148-51.

25. Asuku A, Danborno B, Akuyam S, Timbuak J, Mohammed A, Adamu $\mathrm{L}$. Reference values of body adiposity measures and hand digit ratio (2D:4D) for dyslipidemia: A case study of the Hausa ethnic group in Kano, Nigeria. Journal of Experimental and Clinical Anatomy 2019;18:30 